\title{
土囊袋を用いた表土利用型法面緑化工法の評価
}

\section{The Estimation for the Slope Plantings by using the Forest Surface Soils Packed in Sandbags}

\author{
養父志乃夫* 山田宏之* 中島敦司* 中尾史郎* 松本勝正** \\ Shinobu YABU Hiroyuki YAMADA Atsushi NAKASHIMA \\ Shiro NAKAO Katsumasa MATSUMOTO
}

\begin{abstract}
摘要：従来から行われてきている草本種子を用いた法面緑化工法ではない, 自然の表土と, それに含 まれる埋土種子を利用する緑化工法に関する研究のため, 香川県内において試験施工を行った。樹林 内の表土を尾根部, 中腹部, 谷部の 3 箇所から 1997 年 3 月と 6 月に採取し, 土囊袋に詰めたて勾配 32 度の南西斜面に設置し, 追跡調查を実施した。施工後 2 年目の段階で，土倳採取場所の違いによ り異なる植生が成立した。いずれの区においてもアカメガシワ, ヌルデ等の先駆性の植物が優先的に 成立したが, 尾根部から採取した土壤区では特にススキが密生し, 最大の被覆量を占めた。ススキも 含め，植物被覆量の多い区ほど土壤流亡が少ないことも明らかになった。
\end{abstract}

\section{1.はじめに}

従来から広く行われてきている草本種子を用いた法面緑化工法 ではない，自然の表土と，それに含まれる埋土種子を利用する緑 化工法に関する研究は，既にいくつかの事例を見ることができ る。 ${ }^{123) 45(5) 7}$ しかしながら，佐藤ら (1999) ${ }^{4)}$ の指摘にああるように, 表土利用の緑化工に関しては，技術開発のために必要となる検討 項目が多岐に渡り，現在までの研究成果では不十分な点も多い。 また, 土壌を採取する場所の土壌環境, 植生環境等の違いによる 差異を見極めるためには，数多くの場所での実証的実験が不可欠 と考えられる。そこで本論では, 植生回復の過程の検証と, 土壌 基盤の安定性を向上させる要因の検証を目的に, 香川県内の山間 部の法面において造成地の樹林内表土を採取し，土囊袋に詰めた 植栽基盤を用いて緑化試験を実施した研究結果を報告する。試験 区造成にあたっては, 施工性の向上, 急勾配地への対応, 初期の 土壤流亡への対応等を考慮して, 土囊袋を用いる工法を採用した。

\section{2. 研究方法}

\section{(1) 試験区の造成}

試験区は香川県内の公園造成予定地内に設定した。標高約 $200 \mathrm{~m}$ の地点で, 法面方位は S 34 度W, 平均的な勾配は 32 度で ある。基盤部は軟岩状で非常に硬く, 施工時の平均的な表面硬度 は, 山中式土壌硬度計で $19.3 \mathrm{~mm}$ であった。写真 1 に示すように, 山稜部を削り取った跡地の法面であり, 基盤面からの水分供給は, ほとんど期待できない場所である。更に斜面方位は日射の影響の 大きい南西向きであり, 法面緑化のための条件としては比較的厳 しい状況にある。

試験に使用する表土は試験区付近の山林内から採取した。採取 場所は同一山体の尾根部, 中腹部, 谷部の 3 ヶ所とし, 第 1 回目 の採取を 1997 年 3 月 $16 \sim 18$ 日に, 第 2 回の採取を 1997 年 6 月 17〜18 日に行った。土壤採取時には土猿硬度の測定を実施した。 一般に埋土種子利用の緑化の場合, 秋季から冬季にかけての時期 に土壤採取するのが望ましいとされるが27，不適期施工との比較 という意味で 6 月施工区を設けたものである。まず，山林内の地 表面の落葉落枝を取り除き，腐植に富んだ表層部分（A層）の土 壌を採取した。採取した表土には, 体積比で $10 \%$ のパーライト を保水および固結防止を目的とした土壌改良材として加え，麻袋 に詰めたものを試験に用いた。なお，表土採取地点付近において

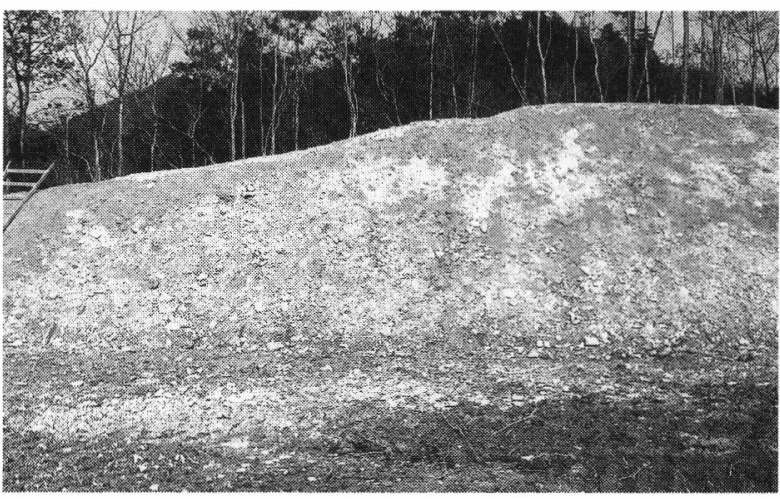

写真-1 試験区の法面（施工前）

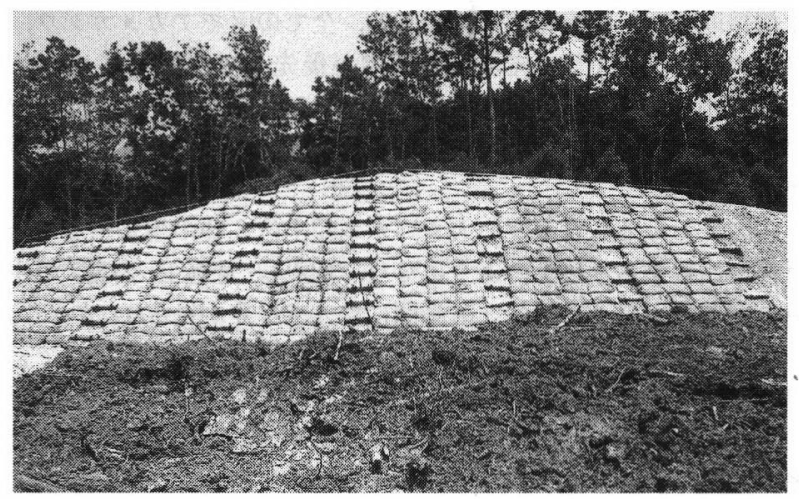

写真－２＼cjkstart試験区の法面（基盤設置後）

は植生調査を実施し，基本的な樹林構成種を把握した。

この植栽基盤材を土壤採取場所, 採取時期別に, それぞれ 6 箇 所に分けて設置した。設置日は土㙵採取日と同一であり, 設置時 期としては 3 月施工区と 6 月施工区に分けられる。土衰袋は下か ら順に斜面上方向に積み上げていき, 固定のための特別な補助材 は使用していない。施工完了後には灌水等維持管理作業を施さず, 経過を観察した。6 月の施工時には 3 月施工区の発芽状況を目視 により記録した。土囊設置時の様子は写真 2 に, 6 種の区別の基 盤の条件は表 1 に示す。土囊設置後に実測した試験区の全面積は $54.3 \mathrm{~m}^{2}$ であり, 土層厚は約 $10 \mathrm{~cm}$ であった。本文中では, この表 1 の分類に従い，(1)区から(6)区の呼称を使用する。

*和歌山大学システム工学部環境システム学科 **和歌山大学地域共同研究センター 


\section{（2）植物被覆状態の調査}

施工後 1 年を経過した 1998 年 6 月 18 日に第 1 回目の調查を行 い，各試験区別に生育している植物種の本数および樹高を把握し た。施工後 2 年目の 1999 年 8 月 $4 \sim 5$ 日には各試験区の毎木調 查を行い，植物 1 本毎の樹高，枝張りを計測した。各々の調査は 各区画ごとに上段, 中段, 下段の 3 箇所に分けて調查を行い, 法 面内の上下方向による環境の差異による影響の把握も試みた。

\section{（3）基盤状態の調查}

1999 年 8 月 $4 \sim 5$ 日に, 基盤材の流亡状況, 土壤硬度，土堹 化学性の調査を行った。流亡状況は設置土囊毎に表層の流亡量を 全体面積に占める割合（\%）で計測し，区画別に基盤流亡率を把 握した。更に, 区画別の流亡率と植物被覆率との関連を相関分析, 回帰分析により解析した。土壤硬度は, 山中式土壤硬度計を用い て各区画内 10 箇所の土壌表面での平均值を求めた。なお，これ に並行して法面基盤部分の表面硬度の測定も実施した。土壌化学 性については，3月施工区の土㙵採取地別の 3 区画から，それぞ れサンプルを採取して, p H, 全窒素量, 全炭素量, CEC の計 測を行った。

\section{3. 結果および考察}

\section{(1) 表土採取地の植生}

表土採取地の植生調查の結果を表 $2-1$ ～ 3 に示す。各区とも コナラ等の落葉広葉樹を中心とした樹林であり, 植物種構成に大 きな差異は無い。

\section{（2）植物被覆状態について}

1997 年 6 月の造成の際には, 3 月施工区の土囊袋から植物の 発芽が観察された。アカマッ，ヤマウルシ，アカメガシワ等の先 駆性の植物と共に, コナラ, イヌッゲ，ムクノキ等多種の植物の 発来が認められた。

(i) 施工後 1 年目

1998 年 6 月 18 日の調查結果を表 3 に示す。各区の上段, 中段, 下段別に生育植物種の生育密度（本／ $\mathrm{m}^{2} ）$ をまとめたあのである。 土壌採取場所, 採取時期に関わらず, 全ての区でアカメガシワ, ヌルデ, タラノキ等の先駆性の植物が優先して生育している。 1997 年 6 月に観察されたコナラ, イヌッゲ, ムクノキ等は全く認 められず, これらの植物は施工後 1 年間の間に枯死したものと考 えられる。

各区における生育密度の大きい木本類上位 5 種の生育密度の合 計值を比較すると図 1 のようになり, (1)区 ( 6 月施工, 谷部) の生 育密度が最も高く，他の 5 区画間には大きな差が見られなかった。

各区内の上下方向での差異を見ると，全体に水分供給の点で有 利な法面下部で生育密度が高く, 最も乾燥する上部では生育状態 が劣る傾向にあった。(5)，(6)区ではネザサの影響で上段部の合計 密度が高いが，これを除けば概ね下段部の生育密度が高い。

(ii) 施工後 2 年目

1999 年 8 月 $4 \sim 5$ 日の生育密度の調査結果を表 4 に示す。木 本類の中で, 生育密度の高い種の構成は 1998 年と大きな変化は 無い。しかし, 出現種数は大幅に増加し, 最も増加した(4)区では 2.6 倍になった。一部の区ではコナラ, ソョゴ, アラカシ等の土 鎄採取地に見られた高木性の樹種が認められた。また，土壤採取 地の植生調查の結果に含まれない種も多数出現したが, これらは, 土壤採取地および試験区の，それぞれ周辺域からの種子の飛来に 起因するものと考えられる。土壤採取地の植生調查において生育 が確認されている種のうち, 今回, 各区において発芽, 生育して いた種の割合は，(1)区で $0.0 \%$ ，(2)区で $13.3 \%$ ，(3)区で 10.0\%， (4)区で $15.4 \%$ ，(5)区で $21.7 \%$ ，(6区で $21.1 \%$ となり，3 月施工 区において相対的に出現割合が高かった。

法面上下間での差異については, 1998 年の調查時と同様に法
表 -1 試験区の区分

\begin{tabular}{|c|c|c|c|}
\hline 区分 & 土猿採取場所 & 面積 & 土猿採取・設置時期 \\
\hline $\begin{array}{l}\text { (1) } \frac{}{\text { (2) }} \\
\text { (3) } \bar{x} \\
\text { (4) } \frac{}{\text { (5) }} \\
\text { (6) }\end{array}$ & $\begin{array}{l}\text { 谷部 } \\
\text { 中腹部 } \\
\text { 尾根部 } \\
\text { 尾根部 } \\
\text { 中腹部 } \\
\text { 谷部 }\end{array}$ & $\begin{array}{r}8.46 \mathrm{~m}^{2} \\
9.42 \mathrm{~m}^{2} \\
10.22 \mathrm{~m}^{2} \\
9.99 \mathrm{~m}^{2} \\
9.10 \mathrm{~m}^{2} \\
7.12 \mathrm{~m}^{2}\end{array}$ & $\begin{array}{l}1997 \text { 年 } 6 \text { 月 } 17 \sim 18 \text { 日 } \\
1997 \text { 年 } 6 \text { 月 } 17 \sim 18 \text { 昌 } \\
1997 \text { 年 } 6 \text { 月 } 17 \sim 18 \text { 昌 } \\
1997 \text { 年 } 3 \text { 月 } 16 \sim 18 \text { 昌 } \\
1997 \text { 年 } 3 \text { 月 } 16 \sim 18 \text { 昌 } \\
1997 \text { 年 } 3 \text { 月 } 16 \sim 18 \text { 至 }\end{array}$ \\
\hline
\end{tabular}

面下部で生育密度, 生育状況とも良好な傾向であった。表 4 のよ うに，(5)区以外は全て下段部の合計生育密度が最大であった。

1998 年と同様に, 各区における生育密度の大きい木本類上位 5 種の生育密度の合計値を比較すると図 2 のようになった。最す 変化の大きい(5)区では生育密度が 13.1 倍に増加しているなど, 全体に植物密度の増加が顕著である。植物の生育状態を見ると, これ以上の生育密度の上昇は考えにくい状態ではあるが, 今後, どのように変化していくのか追跡していく必要があるだろう。

1998 年には(4)区でのみ認められたススキが, 1999 年には(1)区 を除いた全ての区で顕著に繁殖しており, 植物被覆量において大 きな割合を占めるようになった。固体毎の奥行きと幅の値を用い, 全て樹冠を楕円形と見なした場合の被覆面積を求め, 種別に単純 合計した值を植栽地の面積に対する比率（\%) で表した結果が表 5 である。単純合計であるため $100 \%$ を超える場合むあるが, 比 較のために，そのままの值を示した。ここでは被覆率の大きい上 位 5 種のみを記してある。表中, 被覆率の合計値も上位 5 種の合 計である。これから分かるように，(3区および(4)区においてスス キの繁茂が特に顕著であり, 両区とも試験区の大部分をススキが 覆っている状態である。(3)区，(4)区はいずれも尾根部から採取し た表土を用いており，採取地の植生調査ではススキは認められて いないものの, 表土採取地の周囲から種子の供給があり, それが 一斉に発芽, 生育したものと考えられる。ススキの密生が(3)区, (4)区に限られることから, 種子は施工後に飛来したものではなく, 採取地由来のものと考えるのが妥当であろう。

各区とも最も出現数の多いアカメガシワについて, 樹高および 被覆面積を比較した結果が表 6,7 である。樹高, 被覆面積とも に(2)区，(3)区で大きな值を示した。

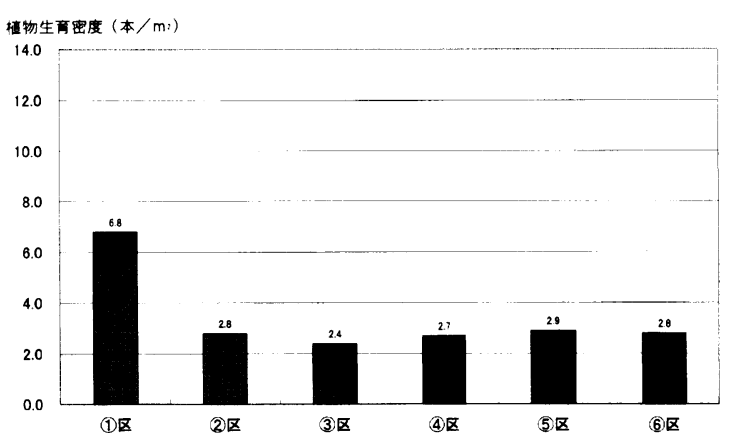

図一 11998 年 6 月の植物生育密度（上位 5 種の合計值） 植物生育密度 $\left(\right.$ 本 $\left./ \mathrm{m}^{2}\right)$

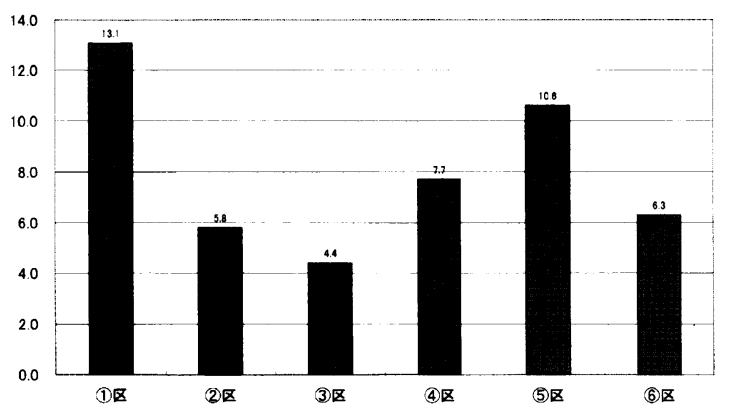

図一21999 年 8 月の植物生育密度（上位 5 種の合計値） 
表 2-1 表土採取地の植生（屋根部）

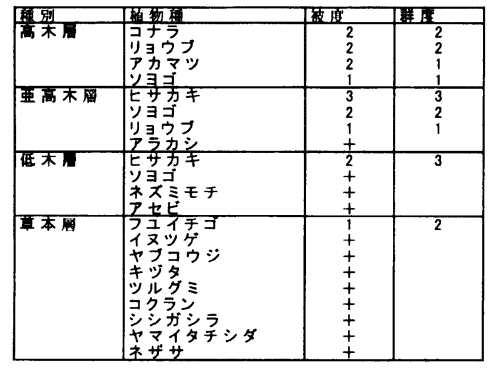

表 2-2 表土採取地の植生（中腹根部）

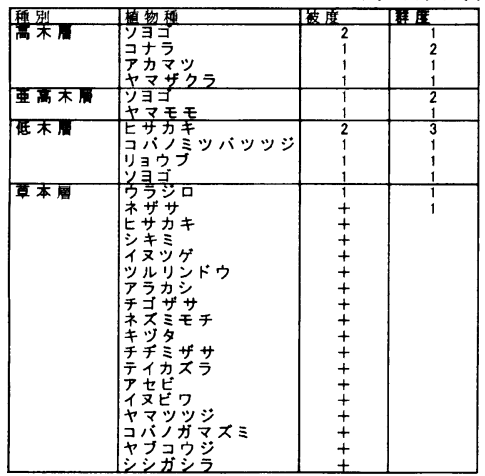

表 2-3 表土採取地の植生（谷部）

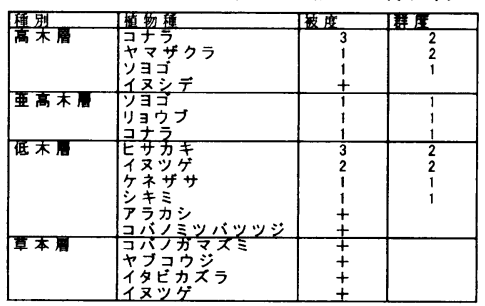

（3）基盤状態について

区別の基盤材の表面流亡率の測定結果を図 3 に示す。植物の被 覆率の高い(1)区，(3)区，(4)区で流亡率が少ない傾向が認められる。 これをより詳細に解析するために, 各区の上段, 中段, 下段別の デー夕を用いて解析を行った。6区それぞれ 3 段分, 合計 18 箇 所の流亡率と, 各々の区の植物被覆率の単純合計值との間の相関 分析を行った結果， 5\%水準で有意な相関関係か認められた $(\mathrm{r}=-$ 0.521)。土壌流亡率 (\%) を目的变数, 合計被覆率（\%) を説明 変数として回帰分析を行うと, $\mathrm{y}=-0.11 \mathrm{x}+33.3$ という回帰式 が得られた（図 4 )。残差標準偏差は土5.91 となり説明精度は悪 いが，植物被覆率が高い場所ほど土壤の流亡率が小さくなる傾向 は明確に示された。この結果から, 土壌基盤の保護という点から は, ススキにより覆われている状態む望ましいものと評価できよう。

土壌硬度の測定結果は, (1)〜6)区とも $5 \sim 10 \mathrm{~mm}$ 程度の值を示し, 膨潤な状態を保っていた。土壌採取地での表土の土壌硬度は 5 $12 \mathrm{~mm}$ であり, ほとんど同じ状態と言えるだろう。一方で法面基盤 部は, 10 筒所の平均で $24.4 \mathrm{~mm}$ と施工時よりも更に硬い状態であっ た。試験区内の 3 本のアカメガシワの根茎を調査したところ, そ のうちの 2 本は写真 3 に示すように, 全ての根が基盤部分に侵入 できず，屈曲した状態になっていることが観察された。このよう に硬く風化が進まないような場所においては, 一時的に植生が定 着しても, 根茎の緊迫力不足から, やがて植物体が崩落, 枯死し てしまう可能性もあり, 法面基盤そのものの改良が必要になるも のと考えられる。

土壌化学性の分析結果は表 8 のようになり, 若干 p H が低い ものの，土壌硬度の測定結果と併せて見れば， 2 年間を経過した 後でも植生基盤として良好な状態であることが確認された。なお,
土壤採取時には同様な分 析を行っていないため, 経時変化の解析は出来な いが，現況において良好 であるという評価は下せ るだろう。

\section{4.まとめ}

施工後 2 年を経過した 段階で, 試験区で生育し ている植物はアカメガシ ワ, ヌルデ，ネムノキ等 の先駆性の木本類とスス キが主であり，土㙵採取 地における現地植生の回 復, という目的から考え ると, 施工後 2 年目程度 では十分な結果が出てい るとは言えない。しかし， アカメガシワ，ススキ等 で密に覆われた区では, 設置した土壌の流亡も少 なく, コナラ, シラカシ, アラカシ等の, 土壤採取 地において高木層を形成 していた木本類の生育が 認められている点などか
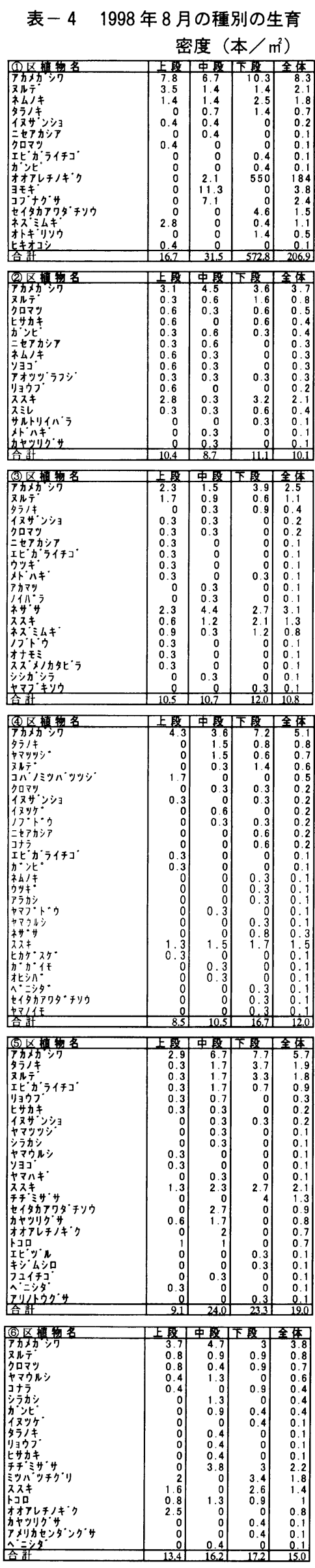

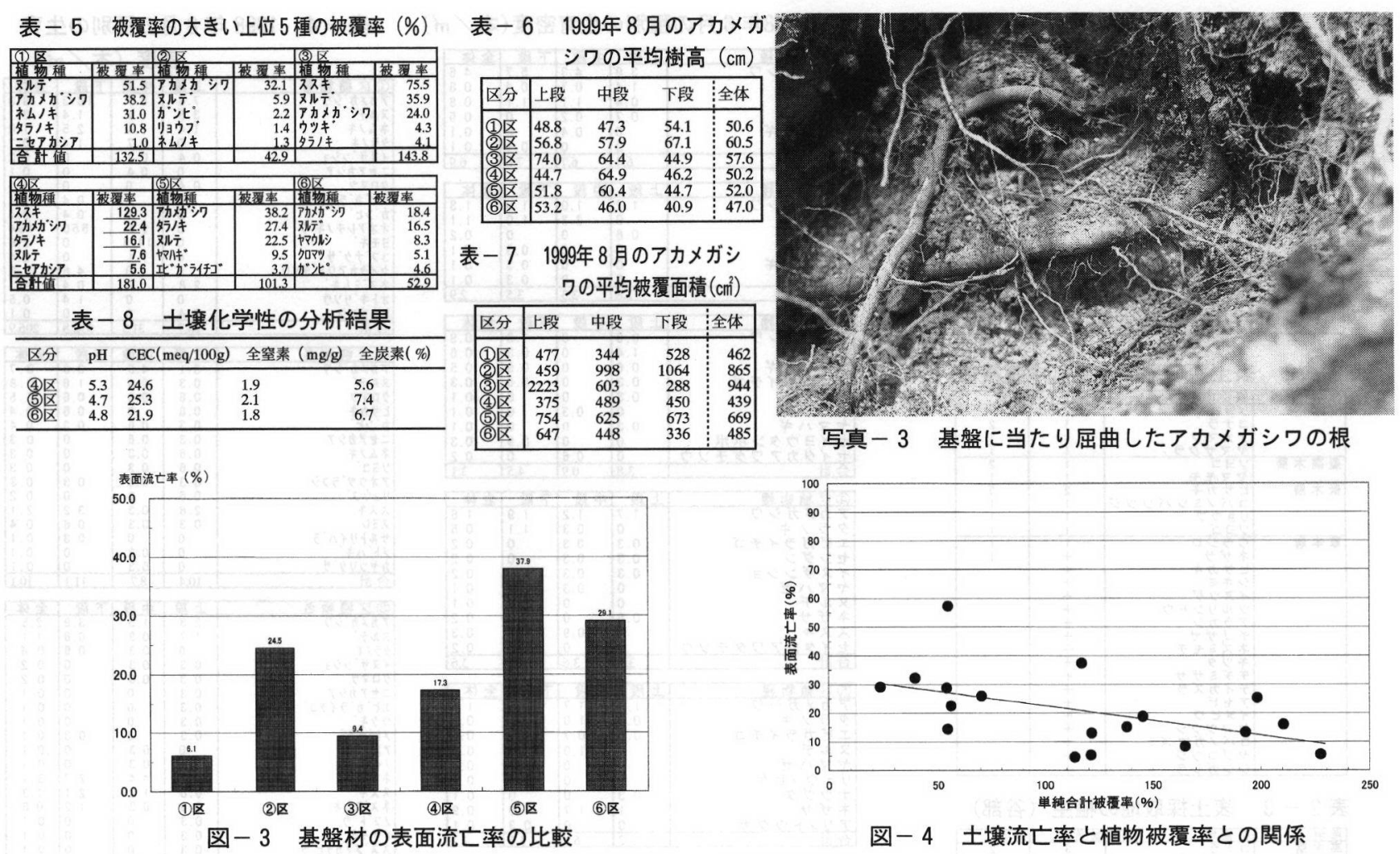

図-4 土壤流亡率と植物被覆率との関係

ら，今後，時間をかけて土壌採取地の樹林地に近い状態を再生で きる可能性む十分にあると考えられる。

土襄設置後，すぐに発芽したコナラ，イヌッゲ，ムクノキ等が 1 年目には全滅していたことから, 今回のように南西斜面の軟岩 上という厳しい条件下では, こういった植物の種子が $2 \sim 3$ 年後, すなわち先駆性の植物が十分に生育してから発芽することが望ま れる。実際に 2 年目に発来したと考えられる植物体も認められた ことから、こういった種子の発芽特性を研究する必要むあるだろ う。

結果を土壤採取地別に見ると, 尾根部から採取した土壌を用い た区で最も被覆率が高く, 土壌も安定していたが, 測定結果が示 すように，これは主にススキの被覆によるものである。植物種構 成の比較では, 尾根部から採取した土猿区でススキの繁茂が顕著 である他は，地区別の差は明確には現れなかった。採取時期によ る違いとしては，3 月施工区において土壤採取地に存在していた 植物種の発生率が高い傾向が認められたものの, 種構成, 被覆密

度等, 全体を通じて共通した特性は見出せなかった。

以上により, 早期に植生により土壌表面が覆われ, 土壌基盤の 安定性が高いという点から, 今回の試験においては, 尾根部から 採取した土壤の使用が最む良好であったと見なせる。しかし， ス スキの繁殖が顕著なため, 将来的に他の区之異なった遷移を示す ことも考えられ，これが最良であるという結論を出すには不十分 である。この点も含め, 今後, 更に追跡調查を行って結論を導く 必要があるだろう。土囊袋については, 2 年目の測定時には大部 分が腐朽消滅していたが, 植物により覆われた場所では, ほとん ど流亡を起こしておらず，初期の土壌流亡防止という点からは十 分に効果的であったと評価できよう。

過去の研究事例 ${ }^{556)}$ 加ら見ても, 法面緑化工法の評価に十分な結 論を得るためには 10 年以上の追跡調查が必要になるものと考え られ, 「現地植生の回復」という目標を評価するためには, 今後 とも長期に渡って継続した調査が必要になると考えられる。

\section{引用および参考文献}

1) 浜田 拓・倉本 宣 (1994)：実生出現法に よるコナラ林の埋土種子集団の研究及びそ の植生管理への応用 : ランドスケープ研究 $58(1), 76-82$

2 ) 亀山章他 (1989)：最先端の緑化技術：ソフ トサイエンス社, 301-307

3) 笠康三郎・福間博史 (1997)：無種子吹付に
よる自然公園内の旧国道法面での植生復元 の試み : 日本緑化工学会研究発表会研究発 表要旨集 $28,209-212$

4 ）佐藤治雄他（1999）：森林表土撒き出しによ る荒廃地緑化に関する基礎研究 : ランドス ケープ研究 62(5), 521-524

5 ）梅原徹他（1983）: 森林表土のまきだしによ る先駆植生の回復法 : 緑化工技術 $9(3), 1-$
8

6) 梅原徹・永野正弘(1997)：「土を撒いて森 をつくる」研究と事業をふりかえって：保 全生態学研究 2(1), 9-26

7 ）米村惣太郎他（1997）: 埋土種子を用いた法 面緑化の研究: 日本緑化工学会研究発表会 研究発表要旨集 $28,255-258$

Summary: The purposes of this study are to obtain a preliminary knowledge for the re-forestry of slope areas with endemic plants stored in a forest soils. The examination area was built on the road side slope in Kagawa pref.. The altitude is about $200 \mathrm{~m}$, the direction of the slope surface is $\mathrm{S} 34^{\circ} \mathrm{W}$ and the average gradient is $34^{\circ}$. On $16-18$, March and 17-18, June 1997, the experimental soil was picked at three different points, first at a ridge area of the mountain, second at a middle area and third at a dale area of the same mountain and packed them in the jute sandbags. After two years the examination area is covered with many plants. The plants density are 4.4-13.1 stems/sqm and 15-26 spaces are confirmed in the one separated area. The predominant plants in this area are Mallotus japonicus, Rhus javanica, Araria elata and other pioneer plants. In the area of ridge soil packing sandbags, a lot of Miscanthus sinensis spring up and hang over the other plants. The well covered areas by these plants are protected from soil erosion. The relation between the erosion ratio $(\%):(y)$ and the sum up plants coverage ratio $(\%):(x)$ is calculated and the regression equation is $y=-0.11 x+33.3$ $\left(r=-0.521^{*}\right)$. 